\title{
Hate Speech: Forensic Linguistics Study
}

\author{
Maria Mintowati \\ Universitas Negeri Surabaya \\ Surabaya, Indonesia \\ mintowati@unesa.ac.id
}

\author{
Hans Yosef Tandra Dasion \\ Universitas Negeri Surabaya \\ Surabaya, Indonesia \\ hans_yosef826@yahoo.com
}

\begin{abstract}
The article entitled "Hate Speech: Forensic Linguistics Study" aims to describe the hate speech delivered by the speaker to the speech partner. The hate speech analyzed in this article is sourced from videos and Facebook that were viral in the mass media in April 2019. Their content is content insulting to the President of the Republic of Indonesia, Joko Widodo. Data collected by the documentation method, then analyzed using the pragmasemantic approach. From the results of the analysis it was found that the hate speech spoken and / or written by $B$ found that the utterances spoken through the video proved to violate the Information of Electronic Transactions Law. Through spoken and written words after being analyzed with a pragmasemantic approach, the preacher is proven to be hateful and threatened to be sent to prison with a minimum sentence of six years. Through lexical and contextual meaning, words, phrases, sentences, and discourse in video uploads, it was revealed that all the language elements contained in the data source proved to contain excactly meanings and aimed at insulting the speech partners. Speech hatred aimed for deliver feeling dislikes, hate, and humiliation to anybody else.
\end{abstract}

Keywords-hate speech; forensic linguistics; pragmasemantic studies

\section{INTRODUCTION}

In recent years, mass media have been invaded by hoaxes, hate speech, and racist speech, and so on. It is suspected that this happened because of improper understanding of communication and informatics reform. In Rahayu [12], the National Commission on Human Rights (Komnas HAM) states that the expression of hatred is very different from freedom of opinion. Amirrudin in Rahayu [12] states that the utterance of hatred is the utterance of hatred. That is very different from freedom of opinion. Freedom of opinion is guaranteed in the 1945 Constitution article 28 paragraph (3). Furthermore, freedom of opinion is the right of Indonesian citizens to express ideas, criticisms, and suggestions based on sound arguments and reasoning. Instead, hate speech is addressed to individuals or groups and communities that violates democracy and human rights (Hak Asasi Manusia). In other words, utterances of hatred are used to attack partners and is said by the preacher. The feelings contain dislike, not one-sided, hatred, threats, insults, or intimidation from the preacher to the partners. The utterance is analyzed by the pragmasemantic approach. Through the pragmasemantic approach, the aforementioned speech will be interpreted in an intact and correct manner.

Haters come from various backgrounds, from ordinary people to officials. Partners said that the target was also the same. The hate speech may come from trivial matters to very fatal things that have an impact on the partners. The utterances are usually produced by teenagers to adults of various levels of education. These utterances can be conveyed directly or indirectly in the form of spoken and / or written speech. Media for the expression of hate speech is often in the form of mass media, such as Facebook, Twitter, and so on.

In this paper, utterances of hatred are selected from those which are derived from the speech of a man under the initial " $\mathrm{B}$ ". The target of hate speech is the President of the Republic of Indonesia, Joko Widodo (Jokowi). The test is conducted by $\mathrm{B}$, a man with many agates. B actually said the hate speech, then was videotaped, uploaded to social media by " $\mathrm{S}$ ", his friend, until it became viral. The video contains hate speech and expressions aimed at Jokowi. The background of the utterance of hate speech is the election campaign for Legislative Candidates (Election Candidates) and Presidential and Vice-Presidential Candidates (Presidential and VicePresidential Election) 2019.

Based on the results of internet search, there are writings related to hate speech. In 2015, Anam and Hafiz [2] discussed the "Police Chief Circular on Handling Hate Speech in the Human Rights Framework". They discussed cases of hate speech, mainly related to religion by basing it on six things, namely (1) the element of crime; (2) the subject base of a crime; (3) the method or method of the crime committed; (4) the purpose of the action itself; (5) the potential effects of hate speech; (6) the approach used to handle hate speech.

The second article is by Octaviani. A. and Atiqa S. [11] titled "Expressions of Hatred in Speech Heaters on Basukibtp Instagram Accounts and their Relevance to Indonesian Language Learning in High School". This paper is a scientific work in the form of a thesis. The results of this study are expressions of hatred impact on the occurrence of exclusion, discrimination, violence against the group, and the destruction of groups. These findings are used as part of Indonesian language teaching materials for high school grade $\mathrm{X}$ students, especially the Basic Competence 10.1 in the Education Level Curriculum.

The third article entitled "The Effect of Hoaxes and the Hate Speech of a Cyber Crime with Simple Technology in 
Social Life in the Community" by Septanto [14]. The results of the study stated that hoaxes have a great impact on people's social lives, have the potential to divide unity, and damage harmony and tolerance in social life.

Fourth, the article entitled "Construction of Hate Speech through Social Media Status" by Wibowo [10]. This paper explores the practice of social media users to pour out their hearts and relate them to privacy concerns that are fading because of the presence of the Information and Electronic Transactions Law (2018).

From the four articles that descend from 2015-2018, it is evident that a pragmasemantic study of hate speech directed at the President of the Republic of Indonesia, Jokowi, is set before the General Election of Presidential and Vice Presidential Candidates has never been done. For this reason, the author examines the utterance of hatred committed by community members towards one of the presidential candidates in the 2019 Election, namely Jokowi.

\section{METHOD}

Data is downloaded from the internet using documentation techniques. Research data in the form of words, phrases, sentences, discourses, and/or pictures or photographs that are identified as hate speech. The hate speech was chosen as a source of data, because it caused unrest among netizens and insulted the leader of the country, namely the President Republic of Indonesia.

Analyzing the data is done by the method of sharing and equivalent method [6]. Data were also analyzed using the pragmasemantic approach. That is, the authors interpret speech and images that indicate hate speech by analyzing the meaning contained in words, phrases, sentences, or discourse by using semantic theory [3] only, but also by pragmatic studies in interpreting the utterances by always considering the context [4].

\section{RESULTS AND DISCUSSION}

The words "Hey Jokowi, the people are disgusted with you ...!" Written on a large piece of white paper and brought B to the highway in the area of Bogor, West Java. It turned out that $\mathrm{B}$ was not just walking while carrying the writing. He also shouted the words, "Jokowi babu China, the President is the worst in the world. D *** ok, bl ** n, id ** $\mathrm{t}$, Choose Prabowo. "The next utterance was" Chinese Babu, PKI. Afraid of being very defensive of Allah, he is a PKI." Action B was recorded on a cellphone by $S$, his friend, and then distributed to the WhatsApp Group. As a result, the video was viral and reaped a lot of netizens' reactions.

In the video B utterance, there are three data coded by the author, namely (B1) "Hei Jokowi rakyat muak jijik sama lu...!", (B2) "Jokowi babu China, Presiden terg***ok di dunia. D***ok,bl**n, id**t, Pilih Prabowo.", dan (B3) "Babu China, PKI. Takut-takut amat bela Allah, emang dia PKI." In the data (B1), there are hateful words or phrases, namely (B1-1) "Hei Jokowi”, (B1-2)“"muak", (B1-3)“ “jijik”, dan (B1-4) "lu”. The speech was delivered by a citizen who addressed the utterance to Jokowi who is an active president of the Republic of Indonesia.

Based on pragmasemantic studies conducted by the author, in (B1-1) ", there is the use of the word" Hey ... "In the Big Indonesian Dictionary (KBBI) online, the word" hey "comes from the word" "hi", in the form of an exclamation to attract attention (calling and so on.) Typically, the word is used to call someone whose name is unknown or unknown to the speaker. In the context of utterances B, it is known clearly that he knows the name of the said partner, because after the use of the word is followed "Jokowi." According to the author, B knows who Jokowi, namely a president who is still actively carrying out his duties. This is supported by the word "people ..." The people referred to in the B statement are the people of Indonesia, the people led by President Jokowi. However, in B statement it is stated that the people led by the President of the Republic of Indonesia are "disgusted by disgust." In the online $\mathrm{KBBI}$, the lexical meaning of the word "disgusted" is already fed up; vomiting, feeling bored or disgusted hearing or seeing. From the lexical meaning, it is known that "disgust" is synonymous with "fed up". This is evident from the second and third meanings of the word "fed up". Contextually from the discourse, B conveyed to the partners said, namely the wider community that the Indonesian people led by President Jokowi were tired, disgusted to the point of wanting to throw up, feeling bored or disgusted seeing Jokowi. This statement is emphasized in the continued utterance which reads "the same you ...!" The word "lu" in KBBI online [5] is a pronoun, but used in a variety of conversations, the variations are not standard. The author believes that B, an ordinary citizen, led by Jokowi, a sovereign president, dared to greet Jokowi with the word "lu!"

In Chaer and Agustina [4], Joos conveyed that there were five languages, namely (1) frozen variety, (2) official variety, (3) business variety, (4) casual variety, and (5) familiar variety. Someone who wants to talk to the president, of course, is not permitted to use casual or familiar varieties. It is certain that B intentionally uses words, phrases and sentences in the data (B1) aimed at insulting the speech partners. In Chaer and Agustina [4], Joos conveyed that there were five languages, namely (1) frozen variety, (2) official variety, (3) business variety, (4) casual variety, and (5) familiar variety. Someone who wants to talk to the president, of course, is not permitted to use casual or familiar varieties. It is certain that $B$ intentionally uses words, phrases and sentences in the data (B1) aimed at insulting the speech partners.

Following this, the results of the analysis for data (B2) "Jokowi Babu China, the President is the worst in the world. D $* * *$ ok, bl ** n, id ** t, Choose Prabowo. "In detikNews, there are four words that are not written in full, namely" terg *** ok ", D *** ok", "bl ** n "," id ** t ". That, according to the writer, was intentionally done by journalists to minimize the negative meaning of the four words. In data (B2), B is addressing the speech partner, Jokowi. In the utterance, B identified the partner said by the name "Jokowi" and his position "President". The purpose of utterance B is to make a statement about who Jokowi is, a "Chinese maid; The President is the worst in the world. D*** ok, bl ** $\mathrm{n}$, id $* * \mathrm{t} . "$ 
Based on pragmasemantic studies, "babu" means women who work as domestic helpers. The use of words with lexical meaning is clearly very different when compared with the facts about Jokowi; a man, not a "maid", let alone a "Chinese maid". Jokowi is a president, who in carrying out his duties cooperates with a number of countries in the world, and one of them is the People's Republic of China. Furthermore, the word "babu" is followed by the word "China". As is known, "China" is a word with nuanced sara. By combining the two words, the contextual meaning that arises is intended to demean, insult a president. According to Adam [1], in the last four years, the cooperation that has been forged between Indonesia and China is (1) economic cooperation between the Coordinating Minister for the Indonesian Economy and the National Commission for Development and Reform of the PRC; (2) cooperation in the construction of institutions and infrastructure between the PRC's National Development and Reform Commission and the Minister of BUMN RI; (3) MoU between the Minister of BUMN RI and the National Development and Reform Commission of the PRC for the Jakarta-Bandung acceleration project.

Law Number 11 Year 2018 regarding Information and Electronic Transactions is one of the legal products of the Ministry of Communication and Information Technology. That's Law regulates information and electronic transactions. In the case of hate speech by $\mathrm{B}, \mathrm{S}$ as the video recorder and disseminator, the sap is also affected. Santoso [13] reported that video recorders and broadcasters of male agate who insulted Jokowi were also detained by the police.

\section{CONCLUSION}

Based on the results of the analysis of hate speech data using a pragmasemantic approach, it can be concluded that the utterances spoken by B through video recorded and uploaded by $\mathrm{S}$ are proven as hate speech addressed to Jokowi, President of the Republic of Indonesia. Through lexical and contextual meaning, words, phrases, sentences, and discourse in video uploads, it was revealed that all the language elements contained in the data source proved to contain negative meanings and aimed at insulting the speech partners.

Suggestion that communicated for speaker is to not be reckless when will deliver message through mass media. Speech don't based emotion hatred, think earlier on previous talk, and choose word that rigjht and polite.

Recommendation that communicated is that speech hatred is thriving in social media. Research about thing still interesting, especially assesment form aspect culture community Indonesia and multidiciplinary other.

\section{REFERENCES}

[1] A. Adam. "Relasi Jokowi dan Cina dalam 4 Tahun Terakhir". 2018. https://tirto.id/relasi-jokowi-dan-cina-dalam-4-tahun-terakhir-c8iE.

[2] M.Ch. Anam., M. Hafiz. "Surat Edaran Kapolri tentang Penanganan Ujaran Kebencian (Hate Speech) dalam Kerangka Hak Asasi Manusia". 2015. http://ojs.ubharajaya.ac.id/index.php/kamnas/article/viewFile/30/23

[3] A. Chaer. Pengantar Semantik Bahasa Indonesia. Bandung: Rineka Cipta. 2009.
[4] A. Chaer., L. Agustina. Sosiolinguistik: Perkenalan Awal. Bandung: Rineka Cipta. 2010.

[5] CNN Indonesia. "Polisi Tangkap Perempuan Blitas yang Hina Jokowi bagai Mumi”. 2019. https://kbbi.web.id/babu https://kbbi.web.id/hai https://kbbi.web.id/muak

[6] Sudaryanto. Metode dan Aneka Teknik Analisis Bahasa. Yogyakarta: Sanata Dharma University Press. 2015.

[7] A. Sudiono. "Polresta Blitar Buru Penghina Presiden". FMB. 2019.

[8] Undang-Undang Dasar Republik Indonesia 1945.

[9] Undang-Undang Nomor 11 Tahun 2008 tentang Informasi dan Transaksi Elektronik.

[10] T.O. Wibowo. "Konstruksi Ujaran Kebencian melalui Status Media Sosial". Artikel dimuat di Channel Jurnal Komunkasi. Vol. 6, No. 2, Oktober 2018, pp. 169-176.

[11] A. Octaviani., S. Atiqa. "Ungkapan Kebencian pada Tuturan Heaters di Akun Instagram Basukibtp dan Relevansinnya terhadap Pembelajaran Bahasa Indonesia di SMA”. Skripsi tidak diterbitkan. Surakarta: Universitas Muhammadiyah Surakarta. 2017

[12] L.S. Rahayu. "Komnas HAM: Ujaran Kebencian Berbeda dengan Kebebasan Berpendapat". Detik News: 2019.

[13] A. Santoso, "Penyebar Video Pria Penuh Akik Hina Jokowi Juga Ditahan Polisi'. Detik News: 2019

[14] H. Septian. "Pengaruh Hoax dan Ujaran Kebencian Sebuah Cyber Crime dengan Teknologi Sederhana di Kehidupan Sosial Masyarakat'. 2018. http://Research.Kalbis.ac.id/research/ 